\title{
Microstructure and Mechanical Properties of TiC Nanoparticle-Reinforced Iron-Matrix Composites
}

\author{
J. M. Kim, ${ }^{1}$ J. S. Park, and H. S. Yun \\ Department of Advanced Materials Engineering, Hanbat National University, Daejeon, Republic of \\ Korea \\ 1 jmk7475@hanbat.ac.kr
}

УДК 539.4

\section{Микроструктура и механические свойства композитных материалов на основе железа, армированных наночастицами ТіС}

\author{
Ж. М. Ким ${ }^{1}$ Ж. С. Пак, Х. С. Юн \\ Факультет инженерии прикладных материалов, Национальный Ханбатский университет, \\ Тэчжон, Республика Корея
}

Композитные материаль на основе железа, армированные равномерно распространенными наночастицами ТіС, получены с помощью планетарного фрезерования в аргоне и последующего горячего прессования. Путем измельчения в течение 6 часов и горячего прессования материала при температуре $1100^{\circ} \mathrm{C}$ и давлении 50 МПа оказалось возможным получить образць композитных материалов с почти максимальной плотностью. Исследованы сферические частииь $\mathrm{TiC}$ и волокнистые мелкодисперсные $\mathrm{Fe}_{3} \mathrm{C}$ фазы, которые образуют матрииу композитного материала на основе железа. Микроструктурный анализ показал, что усредненный диаметр частиц $\mathrm{TiC}$ и длина $\mathrm{Fe}_{3} \mathrm{C}$ фаз уменьшаются с увеличением объемного содержания частии ТіС. Значение предела текучести при сжатии композитных материалов, полученных горячим прессованием, увеличивается пропориионально содержанию частии ТіС: 1,3 ГПа для 7,5\% ТіС. Исследована взаимосвязь между микроструктурными характеристиками и пределом текучести композитных материалов, армированных частицами ТіС. На основе механизма упрочнения Орована можно предположить, что более высокое значение прочности имеет место при большем содержании частиц ТiC, в основном вследствие сокращения расстояния между армирующими наночастицами ТіС.

Ключевые слова: композит с матрицей на основе железа, наночастица ТiC, микроструктура, механическое легирование, горячее прессование.

Introduction. Metals and alloys are often reinforced with ceramics to enhance their strength and wear resistance, and various metal-ceramic composites are widely used in many industrial fields. Among these, the iron- based composites have gained a considerable attention insofar as they possess both excellent mechanical properties and relatively low cost [1-4]. Titanium carbide has been frequently chosen as a reinforcing material to iron matrix due to its high values of hardness, elastic modulus and chemical stability [5-7]. Metal-matrix composites can be classified into various types, including fiber- and particlereinforced. Although the largest enhancement in mechanical properties can be achieved with fiber reinforcements, particle-reinforced composites exhibit an advantage of isotropic properties. There are also diverse ways to fabricate particle-reinforced iron-matrix composites, but powder metallurgy routes involving the addition of $\mathrm{TiC}$ powders to iron powders are often considered as the most suitable method, especially for nanosized reinforcing particles [5-8]. Composite powders can be prepared by many different methods, 
and mechanical alloying (MA) is one of the most appropriate methods that may involve a wide range of reinforcing particle volume fractions and provide the uniform distribution of fine particles in the matrix. Grain size reduction of alloys via mechanical alloying process is also of interest, because it may improve the mechanical strength of these alloys, possibly even without deteriorating their ductility [1].

Indeed, the hardness and yield strength of the metal-matrix composites can be noticeably improved by increasing the volume percent of the reinforcing hard phase in the matrix, but, as with the most metal-matrix composites, the remarkable reduction in ductility through the addition of hard and brittle ceramic particles to the metal is inevitable. The influence of reinforcing particle size on the mechanical properties is complicated. Finer reinforcing particles are expected to increase the strength of a composite more effectively than coarser ones. It has been reported that the yield strength of a cast aluminum alloy was remarkably increased by nanosized $\mathrm{SiC}$ particles, and this improvement was much higher as compared to the reinforcing effect of adding the same amount of microsized $\mathrm{SiC}$ particles [9]. However, very fine particles tend to easily agglomerate, and this may probably result in lower strength and ductility values [4]. A porosity associated with particle agglomeration can be also influential.

However, if very fine spherical TiC particles are uniformly distributed in the metal matrix, the enhancement of hardness and strength may be possible without sacrificing much ductility. Paramsothy et al. [10] showed that asddition of alumina nanoparticles to magnesium alloy could even enhance the ductility. A small amount of submicron-sized alumina particles also could increase the ductility of magnesium attributed to the combination effects of grain size reduction, presence of uniformly distributed fine particles, and slip occurrence on extra nonbasal slip system [11]. But, in case of magnesium matrix composites, an apparently higher ductility was observed when nanosized alumina particles were incorporated, as compared to submicron-sized ones [11].

A few studies have been conducted on TiC nanoparticle-reinforced iron-matrix composites, even though numerous studies on iron composites with micron-sized or larger reinforcing particles have been carried out. Meanwhile, when micron scale TiC particles were used to fabricate $\mathrm{TiC}$ nanoparticle-reinforced iron-matrix composites, considerably long-term milling time was usually required [1]. But, it is expected that the milling time can be significantly reduced if currently commercially available nanosized $\mathrm{TiC}$ particles are directly used. The present research aims to confirm that uniformly distributed TiC nanoparticle-reinforced iron-matrix composite with high strength and high ductility can be fabricated via a relatively fast and simple process. Furthermore, the relationship between microstructure and mechanical properties of nanosized TiC-reinforced iron-matrix composites has not been clarified yet. Therefore, in this research, iron powders and TiC nanoparticles were mechanically alloyed for a short time and hot-pressed to produce the iron-based composites, whereas the correlation between the microstructure and the yield strength of them was mainly discussed with respect to the volume content of TiC.

Experimental Methods. Elemental powder mixtures containing Fe $(0.25$ wt.\% C) with an average powder size of $40 \mu \mathrm{m}$ and TiC with an average size of $20 \mathrm{~nm}$ (MTI Corp, $>99 \%$ ) were used to prepare the composite powders. The compositions of composites were implied to contain 2.5, 5.0, and 7.5\% volume of $\mathrm{TiC}$ nanoparticles. After preliminary mixing of the elemental powder mixtures in a steel jar with a purge of argon for $1 \mathrm{~h}$, mechanical alloying was carried out at room temperature for $6 \mathrm{~h}$ with a high energy vibratory mill using a stainless steel container and $25.4 \mathrm{~mm}$ diameter chrome steel (JIS SUJ2) balls. This comparatively short milling time of $6 \mathrm{~h}$ was set up not in order to obtain a nanosized grain structure, but to provide homogeneously distributed $\mathrm{TiC}$ nanoparticles in the matrix. The volume fraction ratio of the ball charge in the container was about 0.6 and the ratio of the ball to powder was 50:1. To avoid oxidation during the milling process, the container was placed into the high-purity argon atmosphere. 
After the mechanical alloying, the mixed powders were extracted and placed into a graphite mold, and then subjected to the uniaxial hot-pressing at the pressure value of $50 \mathrm{MPa}$ in the argon atmosphere. Coin-shaped specimens with the diameter of $25 \mathrm{~mm}$ were finally produced. The hot-pressing condition, at $1100^{\circ} \mathrm{C}$ for $4 \mathrm{~h}$, was selected through a series of preliminary experiments to assure that the hot-pressed specimens possess at least $99 \%$ density. The increased densification with increased pressing temperature was clearly observed, but the lowest temperature to obtain a high enough density ( $>99 \%$ ) was employed for minimizing the grain growth and manufacturing cost. The density was determined by the Archimedes principle according to ASTM C373-72.

Specimens for optical microscope and scanning electron microscope (SEM, JEOL JSM-5600) examination were prepared to follow the conventional metallographic techniques. The sectioned samples were polished with emery papers of different grits in succession, and then disk-polished with a diamond paste to get a mirror surface. Phase identification was performed by using the X-ray diffractometer (XRD, Rigaku RINT2200) with $\mathrm{CuK} \alpha$ radiation. Transmission electron microscope (TEM, JEOL 2100 F, $200 \mathrm{kV}$ ) equipped with energy dispersive X-ray spectrometer (EDS) was used to investigate the microstructure of hot-pressed specimens in depth. TEM specimens were thinned to less than $100 \mu \mathrm{m}$ by polishing with SiC paper and punched to disks with a diameter of $3 \mathrm{~mm}$, while the final thinning was carried out by iron milling. Compressive tests at room temperature were conducted with an Instron testing machine for the hot-pressed specimens.

Results and Discussion. The diameter of mechanically alloyed iron powders without TiC addition ranged from a few micrometers to $50 \mu \mathrm{m}$. The mean diameter of TiCcontaining powders appeared to be somewhat smaller $(\sim 30 \mu \mathrm{m})$ than that of the iron powders without TiC. However, no clear effects of $\mathrm{TiC}$ content on the powder size were observed. During the high-energy attribution milling process, the elemental powders in the mixture are repeatedly cold-welded and fractured. The powders are gradually workhardened, while the fracture mechanism becomes dominant, resulting in generally decreased size with the milling time. This powder size reduction will be stopped when a steady state is established between the cold welding and the fracture rates. The elemental powders without $\mathrm{TiC}$ nanoparticles are softer than those containing $\mathrm{TiC}$, and it seems quite reasonable that larger powder size is obtained in the absence of $\mathrm{TiC}$ particles, due to a stronger cold-welding effect. Figure 1 shows the XRD analysis patterns for mechanically alloyed powders with and without reinforcing $\mathrm{TiC}$ nanoparticles. It indicates that peaks for $\mathrm{TiC}$ become apparent as the volume percent of $\mathrm{TiC}$ particles is increased $[12,13]$. Insofar as the original iron powders contain about 0.25 wt.\% $\mathrm{C}$, peaks for $\mathrm{Fe}_{3} \mathrm{C}$ phases were expected to be detected, but turned out to be indistinguishable from those for the iron matrix.

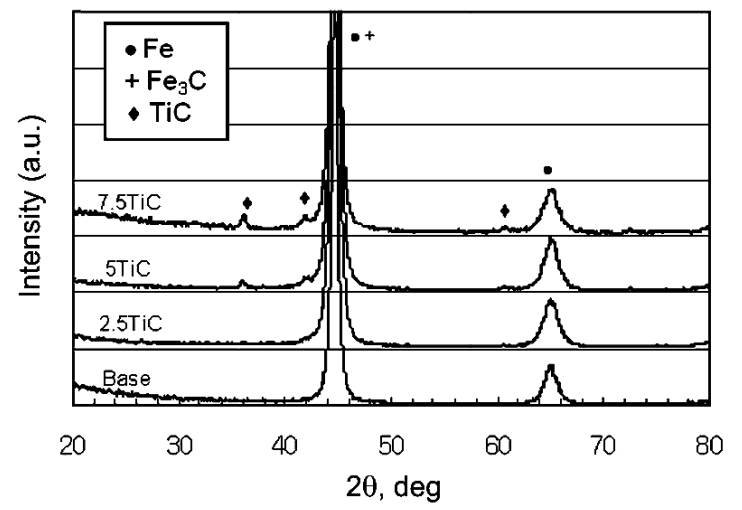

Fig. 1. The XRD analysis results for mechanically alloyed $\mathrm{Fe}+\mathrm{xTiC}$ powders. 
Density measurement and SEM microstructure observations confirmed that almost fully densified composites with no apparent porosity were successfully prepared after the final hot-pressing process. The applied press temperature of $1100^{\circ} \mathrm{C}$, which is relatively low, should be desirable for the future industrial applications [1, 12]. As shown in Fig. 2, comparatively uniformly dispersed fine $\mathrm{Fe}_{3} \mathrm{C}$ phases, as well as $\mathrm{TiC}$ particles, were formed in the hot-pressed composite specimens. The TEM-EDS analyses revealed that the generally fibrous phase and the spherical phase corresponded to $\mathrm{Fe}_{3} \mathrm{C}$ and $\mathrm{TiC}$, respectively.

Table 1 shows that the mean length of fibrous $\mathrm{Fe}_{3} \mathrm{C}$ tends to decrease, while its width increases with increasing the volume percent of $\mathrm{TiC}$. Since the original size of $\mathrm{TiC}$ particles was about $20 \mathrm{~nm}$, a little agglomeration or coarsening of TiC apparently occurred in all the specimens. The mean diameter of $\mathrm{TiC}$ particles was found to decrease with increasing the TiC content. Considering that a milling time of $6 \mathrm{~h}$ was applied [1, 12], it can be concluded that uniformly distributed $\mathrm{TiC}$ nanoparticle-reinforced iron-matrix composites were successfully prepared in a short time. Nowadays, many kinds of nanoparticles are commercially available with reduced costs, so often it would be expedient to mechanically alloy nanoparticles directly with matrix powders, rather than to convert micron-sized particles into the nanosized ones through a prolonged milling.

$\mathrm{T}$ a $\mathrm{b} 1 \mathrm{e} 1$

Morphological Characteristics of $\mathrm{Fine}_{\mathrm{Fe}} \mathrm{C}$ and $\mathrm{TiC}$ Phases in Iron Matrix

\begin{tabular}{|c|c|c|c|}
\hline \multirow{2}{*}{$\begin{array}{c}\text { TiC, } \\
\text { vol.\% }\end{array}$} & \multicolumn{2}{|c|}{$\mathrm{Fe}_{3} \mathrm{C}$} & TiC \\
\cline { 2 - 4 } & Length $(\mu \mathrm{m})$ & Width $(\mu \mathrm{m})$ & Mean diameter $(\mu \mathrm{m})$ \\
\hline 2.5 & 0.82 & 0.10 & 0.124 \\
\hline 5.0 & 0.68 & 0.12 & 0.088 \\
\hline 7.5 & 0.65 & 0.15 & 0.070 \\
\hline
\end{tabular}

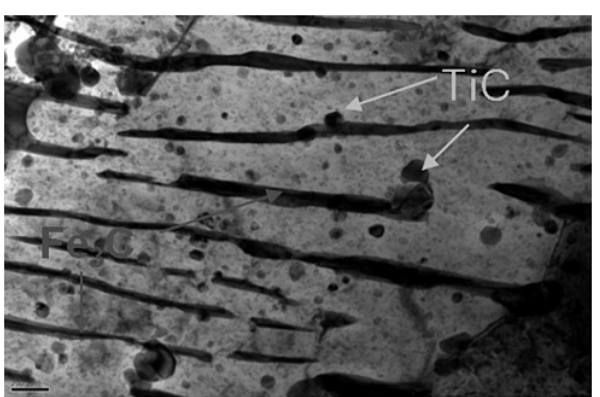

a

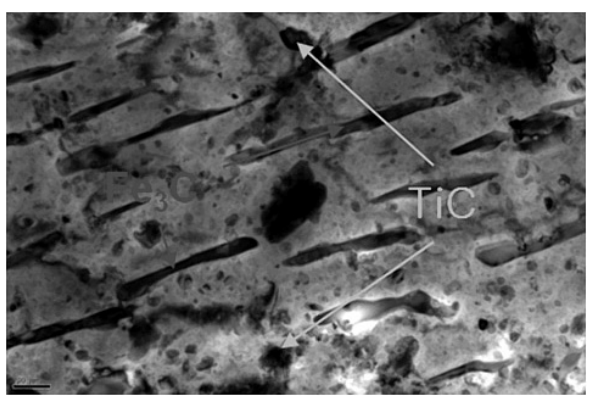

b

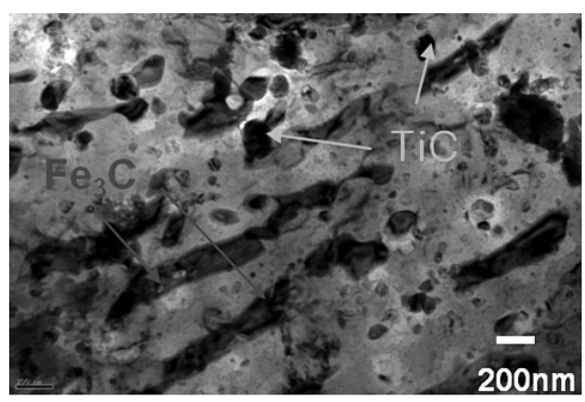

$\mathrm{C}$

Fig. 2. TEM micrographs of hot-pressed specimens showing fine phases: (a) $2.5 \% \mathrm{TiC}$; (b) $5 \% \mathrm{TiC}$; (c) $7.5 \% \mathrm{TiC}$. 
The effect of volume percent of TiC on the compressive properties of the hot-pressed specimens was also investigated. Figure 3 indicates that the yield strength increases gradually with the volume percent of $\mathrm{TiC}$, and all the investigated specimens possess a good ductility (at least $40 \%$ strain). Noteworthy is that a significant enhancement in strength was achieved for high volume content of $\mathrm{TiC}$ without deterioration of the elongation characteristics. This combination of increased strength with retained fairly good ductility is mainly attributed to the refined matrix microstructure, as well as existence of $\mathrm{TiC}$ nanoparticles. In order to differentiate the effect of $\mathrm{TiC}$ particles on the strength from that of $\mathrm{Fe}_{3} \mathrm{C}$ phases, the compressive yield strength of base specimen (without $\mathrm{TiC}$ addition) is also compared in Fig. 4.

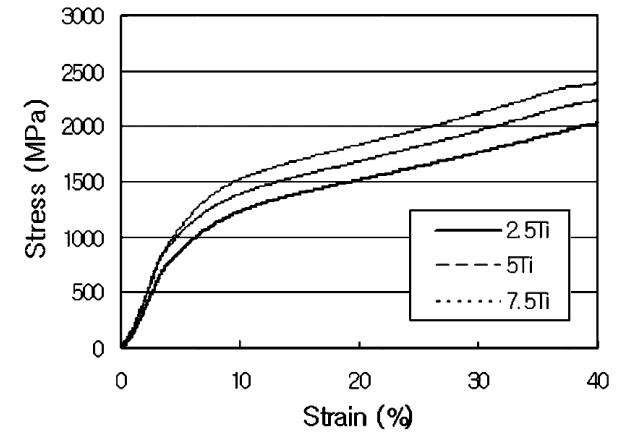

Fig. 3

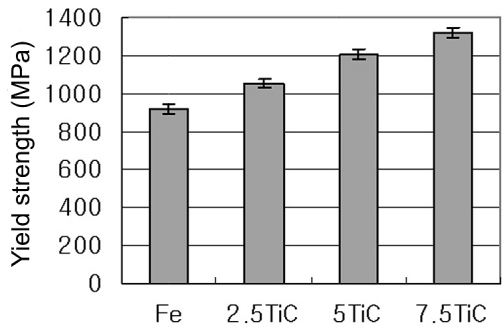

Fig. 4

Fig. 3. Compressive stress-strain curves for hot-pressed specimens.

Fig. 4. Comparison of compressive yield strength for hot-pressed Fe+xTiC specimens.

It has been reported that the strengthening of metal matrix by addition of hard particles is mainly attributed to the load-bearing effect of the reinforcement and the dislocation strengthening in the matrix [14-16]. The load-bearing effect of the reinforcing particles is that the reinforcement can share the applied stress directly with the matrix, whereas the dislocation strengthening is related to the generation of additional dislocations in the matrix owing to the introduced reinforcement. Since these two mechanisms are known to be interrelated/coupled, they can produce a combined effect. For particulereinforced composites, the load-bearing effect is proportional to the volume percent of particles, but the effect of dislocation strengthening in the matrix is related to more diverse mechanisms [17]. One of the main mechanisms contributing to the second effect is the well-known Orowan stress or stress increase required for passing a dislocation through an array of impeding particles. The Orowan stress can be simply written as

$$
\Delta \sigma_{\text {Orowan }}=\frac{G b}{\lambda}
$$

where $G$ is the shear modulus of the matrix, $b$ is the magnitude of the Burgers vector for the dislocation, and $\lambda$ is the distance of the closest approach of the reinforcing particles.

Thus, the effective value of $\lambda$ can be written as

$$
\lambda=\left(\frac{1.81}{\sqrt{f}}-1.63\right) \frac{d}{2},
$$

where $f$ is the volume fraction of the reinforcing particles and $d$ is the diameter of the particles. For the composites in this study, $\Delta \sigma_{\text {Orowan }}$ for a given volume percent $\mathrm{TiC}$ was 
$\mathrm{T}$ a b 1 e 2

Yield Strength Increase of Composite Due to TiC Nanoparticles

\begin{tabular}{|c|c|c|c|c|c||}
\hline $\begin{array}{c}\text { TiC, } \\
\text { vol.\% }\end{array}$ & $\begin{array}{c}\text { Experiment, } \\
\Delta \sigma_{y}, \mathrm{MPa}\end{array}$ & $\lambda, \mathrm{nm}$ & $\begin{array}{c}\Delta \sigma_{\text {Orowan }}, \\
\mathrm{MPa}\end{array}$ & $\begin{array}{c}\Delta \sigma_{1}, \\
\mathrm{MPa}\end{array}$ & $\begin{array}{c}\Delta \sigma_{\text {Orowan }}+\Delta \sigma_{1}, \\
\mathrm{MPa}\end{array}$ \\
\hline 2.5 & 134 & 609 & 67 & 11.5 & 78.5 \\
\hline 5.0 & 286 & 284 & 143 & 23.0 & 166.0 \\
\hline 7.5 & 400 & 174 & 233 & 34.5 & 267.5 \\
\hline
\end{tabular}

calculated and summarized in Table 2. It was assumed that $G=81.6 \mathrm{GPa}$ and $b=0.248 \mathrm{~nm}$ $[18,19]$. Meanwhile, the yield strength increase in the composites due to the load-bearing effect can be expressed as $(f / 2) \sigma_{m}$, where $\sigma_{m}$ is the yield strength of the matrix [14].

Table 2 shows the experimentally measured compressive yield strength of TiCreinforced composites and the calculated values considering the Orowan and the loadbearing mechanisms. Apparently, the actual strength increase obtained in this experiment cannot be completely explained by considering only the above two mechanisms. However, it shows that calculated $\Delta \sigma_{\text {Orowan }}$ is significantly higher than $\Delta \sigma_{1}$, suggesting that the Orowan mechanism plays quite a critical role in composites containing very fine particles. This is due to the relatively low volume fraction and the fine size of the reinforcing particles. It is also noteworthy that the Orowan mechanism becomes more dominant, as compared to the load-bearing mechanism, with increasing the $\mathrm{TiC}$ content because $d$ becomes smaller.

The discrepancy between the experimental strength increase values and those calculated based on the above two mechanisms seems to be mainly attributed to the disregard of the dislocation-strengthening effect that is related to dislocation generation owing to the elastic modulus and thermal expansion coefficient mismatch between the matrix material and reinforcement. Another reason for the discrepancy may be due to the refined matrix microstructure, which is also related to the volume content of TiC. A very fine microstructure is often obtained by the mechanical alloying process, but some grain growth is hard to avoid during the consolidation process at a high temperature. The average grain size with disregard of very fine grains, as estimated from low-magnification SEM micrographs, was reduced from $\sim 20$ to $\sim 10 \mu \mathrm{m}$ as the TiC content was increased. This grain size difference according to the $\mathrm{TiC}$ content can be partly attributed to the fact that the grain growth of the matrix can be suppressed by a particle-pinning effect of fine TiC particles, especially during the densification process at high temperatures [12]. Although the mechanical alloying process employed in this study appeared to reduce the grain size not as effectively as anticipated, the addition of TiC particles has clearly resulted in the average grain size reduction. The reason why the grain was not significantly refined as expected seems due to a relatively short milling time. Therefore, if necessary, both strength and ductility of the TiC-reinforced iron-matrix composites investigated in this study may be further improved by extending the mechanical alloying time. Futhermore, when the grain size becomes extremely small, the Hall-Petch grain size strengthening effect should be very important, too [20].

Conclusions. Uniformly distributed nanosized $\mathrm{TiC}$ particle-reinforced iron-matrix composites were fabricated via short-term mechanical alloying and the following hotpressing procedure at a low temperature. Relatively high compressive yield strength and high ductility could be obtained in the hot-pressed specimens, and the yield strength could be gradually enhanced by increasing the $\mathrm{TiC}$ content. It is proposed that the Orowan strengthening effect provided by nanosized $\mathrm{TiC}$ particles is the main strengthening mechanism for the $\mathrm{TiC}$ particle-reinforced iron-matrix composites. Considering that a 
comparatively short milling time and a low pressing temperature were applied, the currently investigated manufacturing procedure appears to be a very efficient method for obtaining TiC nanoparticle-reinforced iron-matrix composites.

\section{Резгме}

Композитні матеріали на основі заліза, армовані рівномірно розповсюдженими наночастинками $\mathrm{TiC}$, отримано за допомогою планетарного фрезерування в аргоні i подальшого гарячого пресування. Шляхом подрібнення протягом 6 годин і гарячого пресування матеріалу за температури $1100^{\circ} \mathrm{C}$ і тиску 50 МПа можна отримати зразки композитних матеріалів із майже максимальною щільністю. Досліджено сферичні частинки $\mathrm{TiC}$ i волокнисті дрібнодисперсні $\mathrm{Fe}_{3} \mathrm{C}$ фази, які сприяють виникненню матриці композитного матеріалу на основі заліза. Мікроструктурний аналіз показав, що усереднений діаметр частинок $\mathrm{TiC}$ і довжина $\mathrm{Fe}_{3} \mathrm{C}$ фаз зменшуються зі збільшенням об'ємного вмісту частинок ТіС. Значення границі текучості при стисканні композитних матеріалів, отриманих гарячим пресуванням, збільшується пропорційно вмісту ТiC частинок: 1,3 ГПа для 7,5\% ТіС. Досліджено взаємозв'язок між мікроструктурними характеристиками і границею текучості композитних матеріалів, армованих частинками ТiC. На основі механізму зміцнення Орована можна припустити, що більш високі значення міцності відмічаються за більшого вмісту частинок $\mathrm{TiC}$, в основному внаслідок скорочення відстані між армуючими наночастинками ТiC.

1. M. Sheikhzadedh and S. Sanjabi, "Structural characterization of stainless steel/TiC nanocomposites produced by high-energy ball-milling method at different milling times," Mater. Design, 39, 366-372 (2012).

2. J. Wang, Y. Wang, and Y. Ding, "Production of (Ti, V)C reinforced Fe matrix composites," Mater. Sci. Eng. A, 454-455, 75-79 (2007).

3. K. I. Parashivamurthy, R. K. Kumar, S. Seetharamu, and M. N. Chandrasekharaiah, "Review on TiC reinforced steel composites," J. Mater. Sci., 36, 4519-4530 (2001).

4. E. Pagounis and V. K. Lindroos, "Processing and properties of particulate reinforced steel matrix composites," Mater. Sci. Eng. A, 246, 221-234 (1998).

5. H. Zhu, K. Dong, H. Wang, et al., "Reaction mechanisms of the TiC/Fe composite fabricated by exothermic dispersion from Fe-Ti-C element system," Powder Technol., 248, 456-461 (2013).

6. J. Wang and Y. Wang, "In-situ production of Fe-TiC composite," Mater. Lett., 61, 4393-4395 (2007).

7. K. Feng, Y. Yang, B. Shen, and L. Guo, "In situ synthesis of TiC/Fe composites by reaction casting," Mater. Design, 26, 37-40 (2005).

8. T. Yamasaki, Y. J. Zheng, Y. Ogino, et al., "Formation of metal-TiN/TiC nanocomposite powders by mechanical alloying and their consolidation," Mater. Sci. Eng. A, 350, 168-172 (2003).

9. F. Tang, M. Hagiwara, and J. M. Schoenung, "Microstructure and tensile properties of bulk nanostructured Al-5083/SiCP composites prepared by cryomilling," Mater. Sci. Eng. A, 407, 306-314 (2005).

10. M. Paramsothy, X. H. Tan, J. Chan, et al., " $\mathrm{Al}_{2} \mathrm{O}_{3}$ nanoparticle addition to concentrated magnesium alloy AZ81: enhanced ductility," J. Alloys Compd., 545, 12-18 (2012).

11. S. F. Hassan and M. Gupta, "Effect of submicron size $\mathrm{Al}_{2} \mathrm{O}_{3}$ particulates on microstructural and tensile properties of elemental Mg," J. Alloys Compd., 457, 244-250 (2008). 
12. J. Li, Q. Liu, R. Shi, et al., "Preparation and mechanical properties of $\mathrm{Fe}_{3} \mathrm{Al} / \mathrm{TiC}$ composites," J. Mater. Process. Technol., 208, 105-110 (2008).

13. S. Qu, X. Wang, M. Zhang, and Z. Zou, "Microstructure and wear properties of Fe-TiC surface composite coating by laser cladding," J. Mater. Sci., 43, 1546-1551 (2008).

14. S. Scudino, G. Liu, M. Sakaliyska, et al., "Powder metallurgy of Al-based metal matrix composites reinforced with $\beta-\mathrm{Al}_{3} \mathrm{Mg}_{2}$ intermetallic particles," Acta Mater., 57, 4529-4538 (2009).

15. Z. Zhang and D. L. Chen, "Consideration of Orowan strengthening effect in particulate-reinforced metal matrix nanocomposites," Scripta Mater., 54, 1321-1326 (2006).

16. Q. Zhang and D. L. Chen, "A model for predicting the particle size dependence of the low cycle fatigue life in discontinuously reinforced MMCs," Scripta Mater., 51, 863-867 (2004).

17. S. Scudino, G. Liu, K. G. Prashanth, et al., "Mechanical properties of Al-based metal matrix composites reinforced with Zr-based glassy particles produced by powder metallurgy," Acta Mater., 57, 2029-2039 (2009).

18. F. Cardarelli, Materials Handbook, Springer-Verlag, London (2000).

19. J. F. Shackelford, Introduction to Materials Science for Engineers, MacMillan Publishing Co., New York (1985).

20. R. O. Scattergood, C. C. Koch, M. L. Murty, and D. Brenner, "Strengthening mechanisms in nanocrystalline alloys," Mater. Sci. Eng. A, 493, 3-11 (2008).

Received 22. 11. 2013 